\title{
Short communication: The effect of linseed oil and DGAT1 K232A polymorphism on the methane emission prediction potential of milk fatty acids
}

\author{
S. van Gastelen, ${ }^{*} \dagger^{1}$ E. C. Antunes-Fernandes, ${ }^{*} \ddagger^{2}$ K. A. Hettinga, $\ddagger$ and J. Dijkstra† \\ *Top Institute Food and Nutrition, PO Box 557, 6700 AN Wageningen, the Netherlands \\ †Animal Nutrition Group, Wageningen University \& Research, PO Box 338, 6700 AH Wageningen, the Netherlands \\ †Food Quality and Design Group, Wageningen University \& Research, PO Box 17, 6700 AH Wageningen, The Netherlands
}

\begin{abstract}
Several in vivo $\mathrm{CH}_{4}$ measurement techniques have been developed but are not suitable for precise and accurate large-scale measurements; hence, proxies for $\mathrm{CH}_{4}$ emissions in dairy cattle have been proposed, including the milk fatty acid (MFA) profile. The aim of the present study was to determine whether recently developed MFA-based prediction equations for $\mathrm{CH}_{4}$ emission are applicable to dairy cows with different diacylglycerol oacyltransferase 1 (DGAT1) K232A polymorphism and fed diets with and without linseed oil. Data from a crossover design experiment were used, encompassing 2 dietary treatments (i.e., a control diet and a linseed oil diet, with a difference in dietary fat content of $22 \mathrm{~g} / \mathrm{kg}$ of dry matter) and 24 lactating Holstein-Friesian cows (i.e., 12 cows with DGAT1 KK genotype and 12 cows with DGAT1 AA genotype). Enteric $\mathrm{CH}_{4}$ production was measured in climate respiration chambers and the MFA profile was analyzed using gas chromatography. Observed $\mathrm{CH}_{4}$ emissions were compared with $\mathrm{CH}_{4}$ emissions predicted by previously developed MFA-based $\mathrm{CH}_{4}$ prediction equations. The results indicate that different types of diets (i.e., with or without linseed oil), but not the DGAT1 K232A polymorphism, affect the ability of previously derived prediction equations to predict $\mathrm{CH}_{4}$ emission. However, the concordance correlation coefficient was smaller than or equal to 0.30 for both dietary treatments separately, both DGAT1 genotypes separately, and the complete data set. We therefore concluded that previously derived MFA-based $\mathrm{CH}_{4}$ prediction equations can neither accurately nor precisely predict $\mathrm{CH}_{4}$ emissions of dairy cows managed
\end{abstract}

\footnotetext{
Received November 13, 2017.

Accepted February 6, 2018.

${ }^{1}$ Corresponding author: sanne.vangastelen@wur.nl

${ }^{2}$ Current address: KeyToxicology, Yalelaan 104, 3584 CM Utrecht, the Netherlands.
}

under strategies differing from those under which the original prediction equations were developed.

Key words: enteric methane production, milk fatty acid, linseed oil, DGAT1 K232 polymorphism

\section{Short Communication}

Enteric $\mathrm{CH}_{4}$ emission is one of the main targets of greenhouse gas mitigation strategies for the dairy cattle sector (Knapp et al., 2014). Accurate and repeatable measurements of $\mathrm{CH}_{4}$ emission from individual dairy cows are required to evaluate emission factors used in national inventories of greenhouse gas emissions in agriculture, to assess efficacy of mitigation strategies, and to develop protocols for genetic selection for cows with reduced $\mathrm{CH}_{4}$ emission (Hammond et al., 2016). The in vivo $\mathrm{CH}_{4}$ measurement techniques available today are not suitable for precise and accurate large-scale measurements (Hammond et al., 2016). Hence, proxies (i.e., indirect traits related to enteric $\mathrm{CH}_{4}$ production) have been suggested, including the milk fatty acid (MFA) profile. Castro-Montoya et al. (2017) performed a metaanalysis with data from 9 experiments and concluded that MFA did not reliably predict specific amounts of $\mathrm{CH}_{4}$ emitted by dairy cows, whereas MFA has modest potential to differentiate individual dairy cows with high or low $\mathrm{CH}_{4}$ emissions. It has also been shown that the relationship between the MFA profile and $\mathrm{CH}_{4}$ emission can be affected by dietary composition (Dijkstra et al., 2011; Mohammed et al., 2011). The prediction equation developed on diets with a wide range of additives (Dijkstra et al., 2011) overpredicted $\mathrm{CH}_{4}$ emission of cows fed sunflower, flax, and canola seeds (Mohammed et al., 2011), and the prediction equations developed on a wide range of diets including a wide variety of additives (van Lingen et al., 2014) could not accurately predict $\mathrm{CH}_{4}$ emission of dairy cows fed grass- or grass silage-based diets (Dijkstra et al., 2016). The relationship between MFA profiles and $\mathrm{CH}_{4}$ emission is not only affected by dietary composition, but also by lacta- 
tion stage, as demonstrated by Vanrobays et al. (2016). It is, however, unknown whether host genetics can also influence the relationship between the MFA profile and $\mathrm{CH}_{4}$ emission.

The diacylglycerol o-acyltransferase 1 (DGAT1) K232A polymorphism affects not only major milk components, such as protein and fat content, but also their composition, including the MFA profile (e.g., Bovenhuis et al., 2016). Likewise, feeding linseed oil, a dietary strategy to reduce enteric $\mathrm{CH}_{4}$ production, affects the MFA profile (e.g., Kliem et al., 2017). The aim of the present study was to determine whether recent MFAbased prediction equations for $\mathrm{CH}_{4}$ emission are applicable to dairy cows with different DGAT1 genotypes fed diets with and without linseed oil.

Individual cow data from a crossover design experiment with 2 dietary treatments (i.e., a control diet and a linseed oil diet, with a difference in dietary fat content of $22 \mathrm{~g} / \mathrm{kg}$ of DM) and 24 lactating HolsteinFriesian cows (i.e., 12 cows with DGAT1 KK genotype and 12 cows with DGAT1 AA genotype; each group had 6 primiparous and 6 multiparous cows) were used. The experiment has been described by van Gastelen et al. (2017a) and was in accordance with Dutch law and approved by the Animal Care and Use Committee of Wageningen University \& Research (Wageningen, the Netherlands). Dry matter intake, milk production, and enteric $\mathrm{CH}_{4}$ production of cows were measured in climate respiration chambers, described in detail by Heetkamp et al. (2015) and van Gastelen et al. (2015). Daily $\mathrm{CH}_{4}$ production was expressed in grams per day, $\mathrm{CH}_{4}$ yield was expressed in grams per kilogram of DMI, and $\mathrm{CH}_{4}$ intensity was expressed in grams per kilogram of fat- and protein-corrected milk (FPCM). Methane yield was $22.9 \pm 1.52 \mathrm{~g} / \mathrm{kg}$ of DMI for the control diet, $21.5 \pm 1.67 \mathrm{~g} / \mathrm{kg}$ of DMI for the linseed oil diet, 22.3 $\pm 1.76 \mathrm{~g} / \mathrm{kg}$ of DMI for the DGAT1 AA genotype, and $22.1 \pm 1.72 \mathrm{~g} / \mathrm{kg}$ of DMI for the DGAT1 KK genotype $($ mean $\pm \mathrm{SD})$. Dry matter intake was $18.0 \pm 3.25 \mathrm{~kg}$ for the control diet, $17.5 \pm 3.20 \mathrm{~kg}$ for the linseed oil diet, $17.8 \pm 3.24 \mathrm{~kg}$ for the DGAT1 AA genotype, and $17.6 \pm$ $3.23 \mathrm{~kg}$ for the DGAT1 KK genotype. The FPCM yield was $26.8 \pm 5.51 \mathrm{~kg}$ for the control diet, $27.3 \pm 4.62 \mathrm{~kg}$ for the linseed oil diet, $27.2 \pm 5.03 \mathrm{~kg}$ for the DGAT1 AA genotype, and $26.9 \pm 5.11 \mathrm{~kg}$ for the DGAT1 KK genotype. The MFA profile was elucidated using GC, as described by van Gastelen et al. (2015), and expressed in grams per $100 \mathrm{~g}$ of total fatty acids.

The MFA-based $\mathrm{CH}_{4}$ prediction equations reported by Dijkstra et al. (2011; $\mathrm{CH}_{4}$ yield only), van Lingen et al. (2014; $\mathrm{CH}_{4}$ yield and $\mathrm{CH}_{4}$ intensity only), van Gastelen et al. (2017b), and van Gastelen et al. (2018) were used to predict $\mathrm{CH}_{4}$ production, yield, and intensity of each individual cow (Table 1). First, the predicted $\mathrm{CH}_{4}$ emissions, based on the previously mentioned equations, were checked for outliers (i.e., average $\pm 3 \times \mathrm{SD}$ ), but no outliers were detected. Second, the ability of these equations to predict $\mathrm{CH}_{4}$ emission of dairy cows with different DGAT1 genotypes, fed diets with and without linseed oil, was evaluated using the root mean squared prediction error (RMSPE) and the concordance correlation coefficient (CCC), both described in detail by Ellis et al. (2010). The results of these analyses are shown in Table 2 for all data combined, in Table 3

Table 1. The milk fatty acid-based methane prediction equations used in the present study

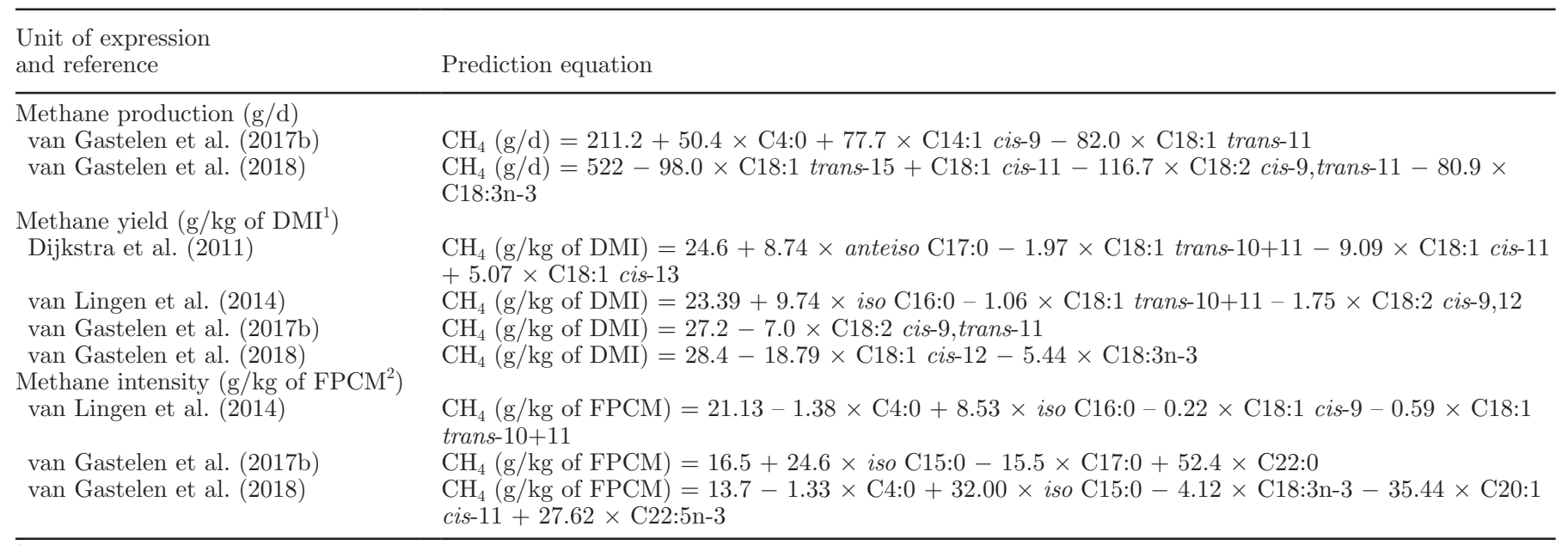

${ }^{1}$ Dry matter intake in $\mathrm{kg} / \mathrm{d}$.

${ }^{2}$ Fat- and protein-corrected milk $(\mathrm{kg} / \mathrm{d})=[0.337+0.116 \times$ fat $(\mathrm{g} / 100 \mathrm{~g}$ of milk $)+0.06 \times$ protein $(\mathrm{g} / 100 \mathrm{~g}$ of milk $)] \times$ milk yield $(\mathrm{kg} / \mathrm{d})(\mathrm{CVB}$, 2012). 
Table 2. The root mean squared prediction error (RMSPE) and concordance correlation coefficient (CCC) results of the milk fatty acid-based methane prediction models (complete data set, $\mathrm{n}=48$ )

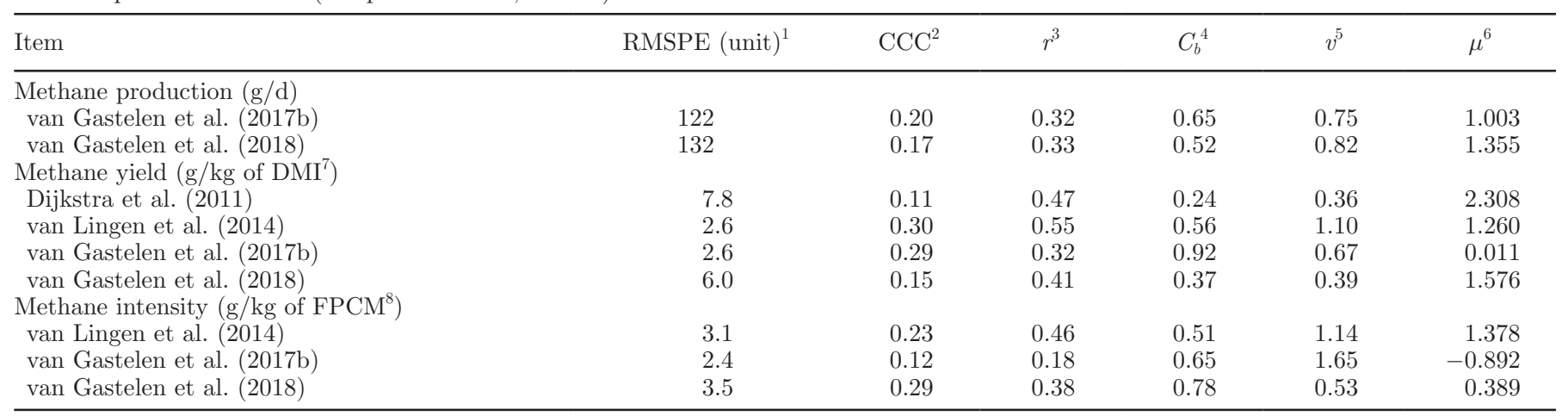

${ }^{1}$ Root mean squared prediction error expressed in $\mathrm{g} / \mathrm{d}, \mathrm{g} / \mathrm{kg}$ of DMI, and $\mathrm{g} / \mathrm{kg}$ of fat- and protein-corrected milk (FPCM) for methane production, yield, and intensity, respectively.

${ }^{2}$ Concordance correlation coefficient, where $\mathrm{CCC}=r \times C_{b}$.

${ }^{3}$ Pearson correlation coefficient; a measure of precision.

${ }^{4}$ Bias correction factor; a measure of accuracy.

${ }^{5}$ Scale shift; change in SD between predicted and observed methane emission.

${ }^{6}$ Location shift; if positive, underprediction; if negative, overprediction.

${ }^{7}$ Dry matter intake in $\mathrm{kg} / \mathrm{d}$.

${ }^{8}$ Fat- and protein-corrected milk $(\mathrm{kg} / \mathrm{d})=[0.337+0.116 \times$ fat $(\mathrm{g} / 100 \mathrm{~g}$ of milk $)+0.06 \times$ protein $(\mathrm{g} / 100 \mathrm{~g}$ of milk $)] \times$ milk yield $(\mathrm{kg} / \mathrm{d})(\mathrm{CVB}$, 2012).

for the control and linseed oil diet separately, and in Table 4 for the DGAT1 KK genotype and DGAT1 AA genotype separately.

With respect to the complete data set $(\mathrm{n}=48)$, the prediction equations did not predict $\mathrm{CH}_{4}$ emissions satisfactorily. The RMSPE of $\mathrm{CH}_{4}$ production was 122 to $132 \mathrm{~g} / \mathrm{d}$, the RMSPE of $\mathrm{CH}_{4}$ yield was 2.6 to $7.8 \mathrm{~g} / \mathrm{kg}$ of DMI, and the RMSPE of $\mathrm{CH}_{4}$ intensity was 2.4 to $3.5 \mathrm{~g} / \mathrm{kg}$ of FPCM. The CCC ranged from 0.17 to 0.20 for $\mathrm{CH}_{4}$ production, from 0.11 to 0.30 for $\mathrm{CH}_{4}$ yield, and from 0.12 to 0.29 for $\mathrm{CH}_{4}$ intensity. These low CCC values were composed of consistently low values for precision $(\mathrm{r}<0.55)$, whereas values for accuracy $\left(C_{\mathrm{b}}\right)$ ranged from low (0.24) to high (0.92). Most of the $\mathrm{CH}_{4}$ prediction equations had a positive $\mu$ value (i.e., location shift), indicating a general underprediction of $\mathrm{CH}_{4}$ emission, with the exception of the prediction equations of van Gastelen et al. (2017b) for $\mathrm{CH}_{4}$ yield (small bias only; consistent with high $C_{\mathrm{b}}$ value) and $\mathrm{CH}_{4}$ intensity (overprediction of $\mathrm{CH}_{4}$ emission). As discussed by Ellis et al. (2010), the variable $v$ (i.e., scale shift) measures the relative difference in standard deviation between predicted and observed values. The prediction equations of van Lingen et al. (2014) for $\mathrm{CH}_{4}$ yield and $\mathrm{CH}_{4}$ intensity had a scale shift close to 1.0, whereas the scale shift of the prediction equation of van Gastelen et al. (2017b) for $\mathrm{CH}_{4}$ intensity was 1.65 . The latter suggests that the variation in the predicted $\mathrm{CH}_{4}$ emissions was smaller than the variation in the observed $\mathrm{CH}_{4}$ emissions. Most of the $\mathrm{CH}_{4}$ prediction equations, however, had a scale shift smaller than 1.0, suggesting that the variation in the predicted $\mathrm{CH}_{4}$ emissions was larger than the variation in the observed $\mathrm{CH}_{4}$ emissions.

Upon dividing the data set into separate data sets representing the control diet $(\mathrm{n}=24)$ and the linseed oil-supplemented diet $(\mathrm{n}=24)$, the equations predicting $\mathrm{CH}_{4}$ emissions performed even less satisfactorily. This is evident by the lower, and sometimes negative, CCC values for both control and linseed oil data sets relative to the complete data set. For the control diet, the scale shift $(v)$ increased considerably (i.e., ranging from 1.18 to 3.47 ) relative to the complete data set, indicating the inability of the $\mathrm{CH}_{4}$ prediction equations to predict the range of observed $\mathrm{CH}_{4}$ emissions. For the linseed oil-supplemented diet, the scale shift varied between 0.57 and 1.87, which is of similar magnitude as for the complete data set. The larger location shift $(\mu)$ values for the linseed oil supplemented diet relative to the complete data set, indicated a biased (in general underpredicted) $\mathrm{CH}_{4}$ prediction. Overall, these results suggest that the dietary composition affects the capability of previously developed MFA-based $\mathrm{CH}_{4}$ prediction equations to predict $\mathrm{CH}_{4}$ emissions of dairy cows.

It should be noted that one would most likely interpret the RMSPE results differently than the CCC results for the control diet. Both RMSPE and CCC decrease for the control diet relative to the complete data set (Table 2 and 3). This is contradictory, because a decrease in RMSPE implies an improvement of the $\mathrm{CH}_{4}$ prediction (Bibby and Toutenburg, 1977), whereas 
Table 3. The root mean squared prediction error (RMSPE) and concordance correlation coefficient (CCC) results of the milk fatty acid-based methane prediction models (control diet and linseed oil diet, both $\mathrm{n}=24$ )

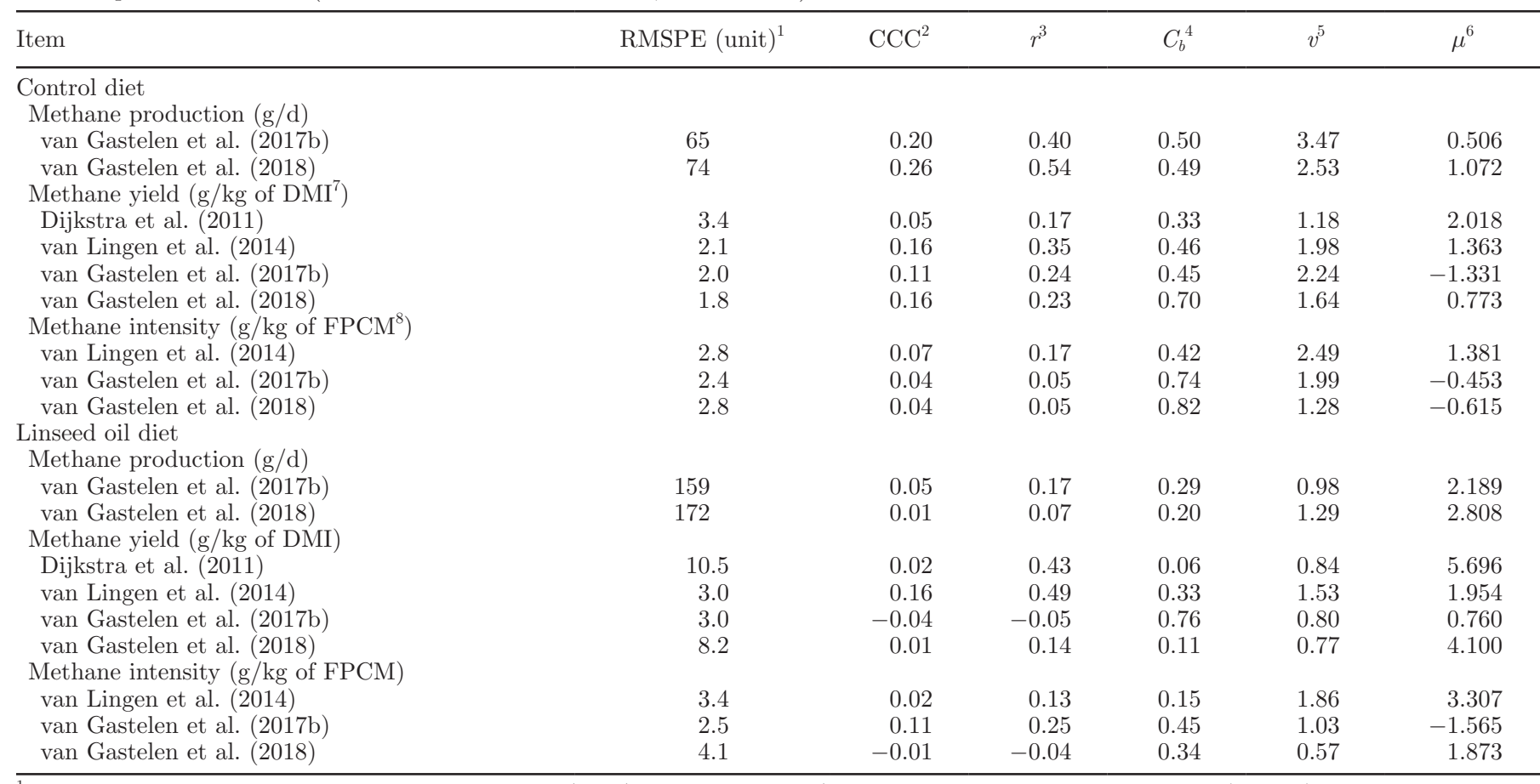

${ }^{1}$ Root mean squared prediction error expressed in $\mathrm{g} / \mathrm{d}, \mathrm{g} / \mathrm{kg}$ of DMI, and $\mathrm{g} / \mathrm{kg}$ of fat- and protein-corrected milk (FPCM) for methane production, yield, and intensity, respectively.

${ }^{2}$ Concordance correlation coefficient, where $\mathrm{CCC}=r \times C_{b}$.

${ }^{3}$ Pearson correlation coefficient; a measure of precision.

${ }^{4}$ Bias correction factor; a measure of accuracy.

${ }^{5}$ Scale shift; change in SD between predicted and observed methane emission.

${ }^{6}$ Location shift; if positive, underprediction; if negative, overprediction.

${ }^{7}$ Dry matter intake in $\mathrm{kg} / \mathrm{d}$.

${ }^{8}$ Fat- and protein-corrected milk $(\mathrm{kg} / \mathrm{d})=[0.337+0.116 \times$ fat $(\mathrm{g} / 100 \mathrm{~g}$ of milk $)+0.06 \times$ protein $(\mathrm{g} / 100 \mathrm{~g}$ of milk $)] \times$ milk yield $(\mathrm{kg} / \mathrm{d})(\mathrm{CVB}$, 2012).

a decrease in $\mathrm{CCC}$ implies a poorer $\mathrm{CH}_{4}$ prediction (Lin, 1989). However, as demonstrated by Ellis et al. (2010) upon evaluating in vivo farm models for $\mathrm{CH}_{4}$ prediction, when prediction equations are unable to describe adequate amounts of the observed variation, $\mathrm{CCC}$ analysis is likely the better evaluation tool. This also applies to the $\mathrm{CH}_{4}$ prediction equations applied to the control diet in the current study, with relatively high $v$ values (ranging from 1.18 to 3.47; Table 3) indicating the inability of the $\mathrm{CH}_{4}$ prediction equations to predict the range of observed $\mathrm{CH}_{4}$ emissions.

Dividing the data set into separate data sets representing the DGAT1 KK genotype $(\mathrm{n}=24)$ and AA genotype $(\mathrm{n}=24)$ hardly affected the RMSPE and $\mathrm{CCC}$ results relative to the complete data set. This indicates that the prediction potential of previously developed MFA-based $\mathrm{CH}_{4}$ equations was not affected by the DGAT1 K232A polymorphism.

The results suggests that dietary composition (i.e., with or without supplementation of linseed oil) af- fects the prediction potential of previously derived MFA-based $\mathrm{CH}_{4}$ prediction equations, whereas the effect of DGAT1 K232A polymorphism seems small. This may be related to the effect of linseed oil and DGAT1 K232A polymorphism on the MFA profile. For example, the prediction equation of van Lingen et al. (2014) for $\mathrm{CH}_{4}$ yield included iso $\mathrm{C} 16: 0$ (positive), C18:1 trans-10+11 (negative), and C18:2n-6 (negative) as explanatory variables. van Gastelen et al. (2017a) demonstrated that the first of these 2 MFA were substantially affected by linseed oil supplementation. To the contrary, according to van Gastelen et al. (2017a), the DGAT1 K232A polymorphism only affected C18:2n-6, whereas the other 2 MFA were not affected. The same patterns was observed for the prediction equation of van Gastelen et al. (2018), which included C18:1 trans- $15+\mathrm{C} 18: 1$ cis- $11, \mathrm{C} 18: 2$ cis-9,trans-11, and C18:3n-3 (all negatively related) as explanatory variables for $\mathrm{CH}_{4}$ production $(\mathrm{g} / \mathrm{d})$. van Gastelen et al. (2017a) demonstrated that these 3 MFA substantially 
increased upon linseed oil supplementation. Contrary to the effect of dietary composition, only C18:3n-3 was significantly affected by the DGAT1 K232A polymorphism, whereas the other 2 MFA were unaffected (van Gastelen et al., 2017a). The effect of linseed oil supplementation on these specific MFA might explain why the $\mathrm{CH}_{4}$ prediction potential of the MFA-based prediction equation of van Lingen et al. (2014) and van Gastelen et al. (2018) was affected by dietary composition. The minor and no effect of DGAT1 K232A polymorphism on these specific MFA might explain why the MFA-based prediction equation of van Lingen et al. (2014) and van Gastelen et al. (2018) predicted $\mathrm{CH}_{4}$ emission equally well for the complete data set and the data sets for the DGAT1 KK and DGAT1 AA genotype separately.

Overall, the present results indicate that dietary composition (i.e., with or without linseed oil), but not the DGAT1 K232A polymorphism, affect the ability of previously derived MFA-based $\mathrm{CH}_{4}$ prediction equations to predict $\mathrm{CH}_{4}$ emission of dairy cows. This dietary effect on the ability to predict $\mathrm{CH}_{4}$ emissions seems to be the result of diet-induced changes in the relationship between MFA profiles and enteric $\mathrm{CH}_{4}$ production. Hence, we concluded that $\mathrm{CH}_{4}$ prediction equations may not be universal and might be valid only when applied to dairy cows managed under similar strategies as those under which the original prediction equations were developed.

\section{ACKNOWLEDGMENTS}

This study was part of the TI Food and Nutrition program "Reduced methane emissions from dairy cows: Towards sustainable dairy cattle production by increased understanding of genetic variation and rumen functioning." Financial support was obtained from the Centraal Bureau Levensmiddelenhandel (CBL; Leidschendam, the Netherlands), Cooperative Cattle Improvement Organization CRV (Arnhem, the Netherlands), Federatie Nederlandse Levensmiddelen

Table 4. The root mean squared prediction error (RMSPE) and concordance correlation coefficient (CCC) results of the MFA-based methane prediction models (DGAT1 AA genotype and DGAT1 KK genotype, both $\mathrm{n}=24$ )

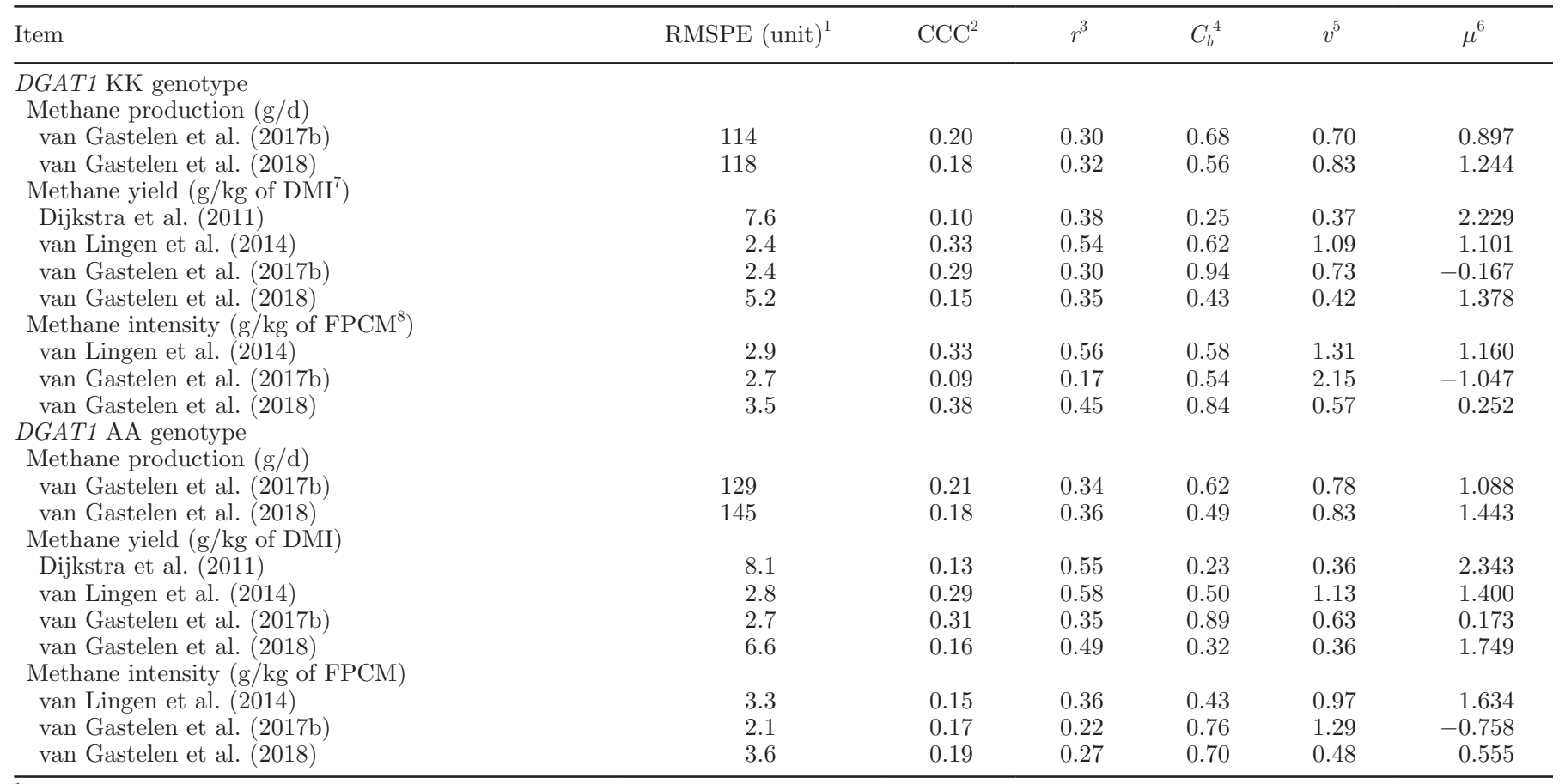

\footnotetext{
${ }^{1}$ Root mean squared prediction error expressed in $\mathrm{g} / \mathrm{d}, \mathrm{g} / \mathrm{kg}$ of DMI, and $\mathrm{g} / \mathrm{kg}$ of fat- and protein-corrected milk (FPCM) for methane production, yield, and intensity, respectively.

${ }^{2}$ Concordance correlation coefficient, where $\mathrm{CCC}=r \times C_{b}$.

${ }^{3}$ Pearson correlation coefficient; a measure of precision.

${ }^{4}$ Bias correction factor; a measure of accuracy.

${ }^{5}$ Scale shift; change in SD between predicted and observed methane emission.

${ }^{6}$ Location shift; if positive, underprediction; if negative, overprediction.

${ }^{7}$ Dry matter intake in $\mathrm{kg} / \mathrm{d}$.

${ }^{8}$ Fat- and protein-corrected milk $(\mathrm{kg} / \mathrm{d})=[0.337+0.116 \times$ fat $(\mathrm{g} / 100 \mathrm{~g}$ of milk $)+0.06 \times$ protein $(\mathrm{g} / 100 \mathrm{~g}$ of milk $)] \times$ milk yield $(\mathrm{kg} / \mathrm{d})(\mathrm{CVB}$, 2012).
} 
Industrie (FNLI; The Hague, the Netherlands), Lely Industries NV (Maassluis, the Netherlands), Ministry of Economic Affairs (The Hague, the Netherlands), Qlip BV (Zutphen, the Netherlands), Wageningen University \& Research (Wageningen, the Netherlands), and ZuivelNL (Zoetermeer, the Netherlands).

\section{REFERENCES}

Bibby, J., and T. Toutenburg. 1977. Prediction and Improved Estimation in Linear Models. John Wiley \& Sons, Chichester, UK.

Bovenhuis, H., M. H. P. W. Visker, N. A. Poulsen, J. Sehested, H. J. F. van Valenberg, J. A. M. van Arendonk, L. B. Larsen, and A. J. Buitenhuis. 2016. Effect of the diacylglycerol o-acyltransferase 1 (DGAT1) K232A polymorphism on fatty acid, protein, and mineral composition of dairy cattle milk. J. Dairy Sci. 99:3113-3123.

Castro-Montoya, J. M., N. Peiren, J. Veneman, B. De Baets, S. De Campeneere, and V. Fievez. 2017. Predictions of methane emission levels and categories based on milk fatty acid profiles from dairy cows. Animal 11:1153-1162.

CVB. 2012. Chemische samenstellingen en nutritionele waarden van voedermiddelen (in Dutch). CVB (Centraal Veevoederbureau), The Hague, the Netherlands.

Dijkstra, J., S. van Gastelen, E. C. Antunes-Fernandes, D. Warner, B. Hatew, G. Klop, S. C. Podesta, H. J. van Lingen, K. A. Hettinga, and A. Bannink. 2016. Relationships between milk fatty acid profiles and enteric methane production in dairy cattle fed grass- or grass silage-based diets. Anim. Prod. Sci. 56:541-548.

Dijkstra, J., S. M. van Zijderveld, J. A. Apajalahti, A. Bannink, W. J. J. Gerrits, J. R. Newbold, H. B. Perdok, and H. Berends. 2011. Relationships between methane production and milk fatty acid profiles in dairy cattle. Anim. Feed Sci. Technol. 166-167:590-595.

Ellis, J. L., A. Bannink, J. France, E. Kebreab, and J. Dijkstra. 2010. Evaluation of enteric methane prediction equations for dairy cows used in whole farm models. Glob. Change Biol. 16:3246-3256.

Hammond, K. J., L. A. Crompton, A. Bannink, J. Dijkstra, D. R Yáñez-Ruiz, P. O'Kiely, E. Kebreab, M. A. Eugène, Z. Yu, K. J. Shingfield, A. Schwarm, A. N. Hristov, and C. K. Reynolds. 2016. Review of current in vivo measurements techniques for quantifying enteric methane emission from ruminants. Anim. Feed Sci. Technol. 219:13-30.

Heetkamp, M. J. W., S. J. J. Alferink, T. Zandstra, P. Hendriks, H. van den Brand, and W. J. J. Gerrits. 2015. Design of climate respiration chambers, adjustable to the metabolic mass of subjects.
Pages $35-56$ in Indirect Calorimetry. Techniques, Computations and Applications. W. J. J. Gerrits and E. Labussière, ed. Wageningen Academic Publishers, Wageningen, the Netherlands.

Kliem, K. E., D. J. Humphries, C. K. Reynolds, and R. Morgan. 2017. Effect of oilseed type on milk fatty acid composition of individual cows, and also bulk tank milk fatty acid composition from commercial farms. Animal 11:354-364.

Knapp, J. R., G. L. Laur, P. A. Vadas, W. P. Weiss, and J. M. Tricarico. 2014. Invited review: Enteric methane in dairy cattle production: Quantifying the opportunities and impact of reducing emissions. J. Dairy Sci. 97:3231-3261.

Lin, L. I. K. 1989. A concordance correlation coefficient to evaluate reproducibility. Biometrics 45:255-268.

Mohammed, R., S. M. McGinn, and K. A. Beauchemin. 2011. Prediction of enteric methane output from milk fatty acid concentrations and rumen fermentation parameters in dairy cows fed sunflower, flax, or canola seeds. J. Dairy Sci. 94:6057-6068.

van Gastelen, S., E. C. Antunes-Fernandes, K. A. Hettinga, and J. Dijkstra. 2017b. Relationships between methane emission of Holstein Friesian dairy cows and fatty acids, volatile metabolites and non-volatile metabolites in milk. Animal 11:1539-1548.

van Gastelen, S., E. C. Antunes-Fernandes, K. A. Hettinga, and J. Dijkstra. 2018. The relationship between milk metabolome and methane emission of Holstein Friesian dairy cows-Metabolic interpretation and prediction potential. J. Dairy Sci. 101:2110-2126. https://doi.org/10.3168/jds.2017-13334.

van Gastelen, S., E. C. Antunes-Fernandes, K. A. Hettinga, G. Klop, S. J. J. Alferink, W. H. Hendriks, and J. Dijkstra. 2015. Enteric methane production, rumen volatile fatty acid concentrations, and milk fatty acid composition in lactating Holstein-Friesian cows fed grass silage- or corn silage-based diets. J. Dairy Sci. 98:1915-1927.

van Gastelen, S., M. H. P. W. Visker, J. E. Edwards, E. C. AntunesFernandes, K. A. Hettinga, S. J. J. Alferink, W. H. Hendriks, H. Bovenhuis, H. Smidt, and J. Dijkstra. 2017a. Linseed oil and DGAT1 K232A polymorphism: Effects on methane emission, energy and $\mathrm{N}$ metabolism, lactation performance, ruminal fermentation, and rumen microbial composition of Holstein-Friesian cows. J. Dairy Sci. 100:8939-8957.

van Lingen, H. J., L. A. Crompton, W. H. Hendriks, C. K. Reynolds, and J. Dijkstra. 2014. Meta-analysis of relationships between enteric methane yield and milk fatty acid profile in dairy cattle. J. Dairy Sci. 97:7115-7132

Vanrobays, M.-L., C. Bastin, J. Vandenplas, H. Hammami, H. Soyeurt, A. Vanlierde, F. Dehareng, E. Froidmont, and N. Gengler. 2016. Changes throughout lactation in phenotypic and genetic correlations between methane emissions and milk fatty acid contents predicted from milk mid-infrared spectra. J. Dairy Sci. 99:7247-7260. 